\title{
The Role of Real Options in the Takeover Premia in Mergers and Acquisitions
}

\author{
Leonidas G. Barbopoulos $^{\mathrm{a}} \quad$ Louis T.W. Cheng $\quad$ Yi Cheng ${ }^{\mathrm{b}} \quad$ Andrew Marshall ${ }^{\mathrm{c}}$ \\ aUniversity of St. Andrews $\quad$ b Hong Kong Polytechnic University $\quad{ }^{c}$ University of Strathclyde
}

\begin{abstract}
This paper applies a real option framework to suggest that the takeover premia in mergers and acquisitions can be influenced by (a) the pre-bid ownership of target and (b) the real option characteristics of both acquirer and target firms. Our findings show that pre-bid ownership reduces the takeover premia, which is consistent with the argument that pre-bid ownership reduces information asymmetry. However, we find that the takeover premia is higher when both the acquirer and target firms exhibit real option capacity as measured by positive risk-return sensitivity. As a result, an acquirer with real option capacity is willing to pay higher takeover premia for an option embedded in the target firm.
\end{abstract}

Keywords: Real options; Takeover premia; Acquirer abnormal returns; Target abnormal returns.

JEL Classification: G12, G14, G30, G34. 


\section{Introduction}

Reflecting the importance of mergers and acquisitions (M\&As) in shaping the modern corporation, a voluminous literature has emerged investigating the determinants of takeover premia offered in M\&As (higher purchase price in comparison to the current market value of target firm). ${ }^{1}$ These determinants include managerial motivations (Amihud and Lev, 1981), agency costs (Seth et al., 2002), acquiring and target firms' characteristics (Denis et al., 2002), regulations (Rossi and Volpin, 2004), international taxation (Huizinga et al., 2012), and other merging firms- and deal-specific features (for a review, see Sudarsanam, 2010). These studies offer compelling evidence regarding the impact of several important factors on the distribution of takeover premia offered in M\&As. However, in this paper we suggest an important aspect, that has received limited attention, relates to the impact of several dynamics embedded on real option characteristics of the firms. We argue that this can significantly affect the takeover premia.

The 'real option' perspective is not new in the capital investment literature. There has been awareness that many of the investment 'decisions under uncertainty' can be viewed as real option problems (Copeland and Antikarov, 2001; Schwartz and Trigeorgis, 2001). Along these lines, the real option analysis has been applied in investments such as R\&D (Mitchell and Hamilton, 1988), emerging markets (Kogut and Kulatilaka, 1994), and natural resource investments (Morck et al., 1989; Bjerksund and Ekern, 1990), among others. Relating real options to M\&As is also not new in the academic literature (Bruner, 2004). In particular, Smith and Triantis (1995) point out that the target firm may have growth options that the acquiring firm may consider as very valuable. Through a series of acquisitions of small

\footnotetext{
${ }^{1}$ For a review of these studies see Eckbo (2009).
} 
fractions of the target firm, acquirers can develop a collection of growth options that allows them to further enhance their competitive position. Agliardi et al. (2016) present a model that leverage ratios increase in M\&As that create significant new growth options. In the empirical tests of their trade-off model of leverage changes in M\&As they find that leverage increases in merging firms that create significantly larger growth options.

We are motivated to extend further the real option in M\&As by connecting two main arguments. First, we rely on Higgins and Rodriguez (2006) who suggest that alliances with a target allows potential bidders to gain sufficient information in the pre-acquisition period in order to know what they are buying. This contention is similar to arguments suggesting that strategic alliances and joint ventures in foreign direct investment are effective tools for firms to acquire "time-to-build" real options aiming to tackle environmental and social uncertainty. Environmental uncertainty stems from the lack of information about the market environment, and social uncertainty is the lack of understanding of the partner's attitude towards the alliance (Tong et al., 2008; McCarter et al., 2011). ${ }^{2}$ We believe that this idea can also be extended in M\&As, as acquirers are concerned about whether their future investment in targets will yield a sufficiently high return (environmental uncertainty) based on the acquisition price (i.e. takeover premia and the post-acquisition integration), information asymmetry in the M\&A process, as well as their unfamiliarity with the targets management (social uncertainty). Acquirers could get access to previous unavailable internal information

\footnotetext{
2 Time-to-build options are embedded in investment projects in which firms choose a contingent plan for making sequential expenditure by constantly learning from new information (Majd and Pindyck, 1987). Uncertainty determines the value of time-to-build real options and further affects firms' decision of how much ownership to acquire and how they will develop their stake (Kulatilaka and Perotti, 1998; Folta and Miller, 2002). Folta and Miller (2002) show that acquisition of majority stakes is more likely in the presence of lower uncertainty as acquirers would prefer partial acquisitions rather than commit to large irreversible investment when faced with greater uncertainties and information asymmetry.
} 
by achieving a pre-ownership stake in the target (i.e., toehold). As a result, this stake may help them to develop a relation with the target management (possibly including their views on the M\&As), which should resolve social uncertainty. As new information arrives and information asymmetry is gradually reduced, and acquirers have the flexibility to halt, abandon or expand their investment in the target firm. For instance, Wong (2009) shows that the existence of an abandonment option can affect a firm's investment decision. ${ }^{3}$ Therefore, acquirers use pre-bid ownership to obtain time-to-build real options in order to mitigate environmental and social uncertainty that exists in a full takeover. There is some debate in the literature on the effects of acquirers' toehold and takeover premia in M\&As. Betton and Eckbo (2000) suggest that pre-bid ownership reduces competition and target resistance, which leads to a lower takeover premia offered to the target. We suggest that the reason the pre-bid ownership reduces competition, target resistance as well as offer premia, is related to the real option imbedded in the pre-bid ownership. Pereira and Rodrigues (2019) develop a dynamic real options model for the timing and terms of mergers. Under perfect information, they find that the merger terms must depend on the negotiating power of each firm. As prebid ownership effectively makes the acquirer an insider with access to information and knowledge of the management and decision making of the target firm. This should lead to the possibility of negotiating a better deal and being able to assess more accurately the takeover premia. ${ }^{4}$

Second, we develop arguments along those in Bradley et al. (1988) who suggest that

\footnotetext{
${ }^{3}$ Shibata and Wong (2019) further show that a firm can determine the optimal investment timing when the costly reversible ratio of investment at the time of stopping the project can be determined.

${ }^{4}$ It is also possible that the potential acquirer could conclude that the subsequent acquisition is no longer attractive and can choose to abandon the M\&As project. However, our study does not cover this research direction.
} 
synergistic value created in takeovers depends on how the acquirer can capitalize on the combined investment opportunities. Following this, Grullon et al. (2012) argue that in the majority of M\&As acquirers are buying the growth options of the target and hold flexibility in deploying resources to develop the acquired growth options. They suggest that investment or growth opportunities and the real option value are positively related. They develop a real option measure based on sensitivity of firm level stock return to volatility changes. If a firm has more real options, it will take advantage of the higher volatility, leading to greater sensitivity of stock return to volatility changes. We also connect this to Bena and Li (2014) who suggested that firms with a technological overlap (like-buys-like) have a higher probability to be involved in M\&As. We use target and acquirer characteristics to construct a real option measure related to merger-pair and examine its effect on the takeover premia, based on Grullon et al. (2012) and Bena and Li (2014). Therefore, contrary to the effect of the pre-bid ownership stake, we expect that if both acquirer and target in a merger matchedpair contain a positive real option, this should have a positive influence on the takeover premia offered to the target.

We contribute to the literature by analysing if, and if so to what extent, real options in the M\&A process influence the takeover premia offered to the target through two real option related characteristics, namely: (a) pre-bid ownership stake, and (b) acquirer and target firm level characteristics including the risk-return sensitivity of merger matched-pairs and the technological overlap (referred to as like-buys-like). We argue that pre-bid ownership (i.e., toehold, which is defined as prior percentage of ownership) can be viewed as a form of real option and the subsequent acquisition of the target is the exercise of the real option. 
We conjecture that pre-bid ownership is a form of real option and the subsequent acquisitions as evidence of exercising such a real option is supported by Smith and Triantis (1995). Acquirers use pre-bid ownership to obtain time-to-build real options in order to mitigate environmental uncertainty and social uncertainty in a full takeover. Consequently, we expect that our measure of pre-bid ownership as a form of time-to build real option is negatively related to the takeover premia. Grullon et al. (2012) provides us with a proxy for the level of real options within a firm. They find that the positive relationship between the firm level stock return to changes in volatility is due to the real options held by the firm. The more real option the firm hold, the higher the sensitivity coefficient of firm level stock return to changes in volatility is. Therefore, the sensitivity coefficient can serve as a measurement proxy for the firm's real option level. With this measurement of real options, it becomes feasible to investigate how the real option level of the acquirer and target will affect the transaction incidence and how the acquirer and target will match with each other.

In terms of the sensitivity of statistical properties of takeover premia to the target firm's domicile, it has been shown that compared to domestic acquirers, foreign acquirers (i.e. acquirers engaged in cross-border acquisitions (CBA)) offer a higher takeover premia to their targets (Harris and Ravenscraft, 1991). ${ }^{5}$ The literature also shows that, due to the differences in culture, management style, and product market condition across countries, social uncertainty and environmental uncertainties are larger in CBA than in domestic counterparts. These findings suggest that CBAs are an interesting sample of takeovers to investigate whether, and to what extent, our real option arguments relate to takeover premia

\footnotetext{
${ }^{5}$ Such excess premia is often considered as one of the reasons for the decline in acquirers' value around CBA announcements (Moeller and Schlingemann, 2005).
} 
offered in domestic versus foreign target M\&As.

Our findings add to the evidence on the determinants of the takeover premia offered in M\&As by providing insights into (a) the role of real options in the form of pre-bid ownership and (b) the positive risk-return sensitivity of the acquiring and target firms. First, we find there is a lower takeover premia offered in M\&As where there was a pre-bid ownership stake. This is consistent with our conjecture that through gaining a pre-bid ownership acquirers are buying a real option which reduces information asymmetry by which enabling them to gain access to privileged information and familiarity with senior management of the target firm. If the information gained through the pre-bid target ownership is valuable in assessing the post-acquisition value of the firm, the acquirer will exercise their option as it allows them to 'negotiate' for a lower premia for their target firms and/or pay a price that is more reflective of the true value of the target under the control of acquirer. Secondly, we find that the takeover premia is higher when both the acquirer and target exhibit positive risk-return sensitivity. This supports our view that merger pairs with positive real options are expected to generate additional value, leading to the buyer paying a higher premia. In the literature there are both theoretical models and empirical evidence on the cross-sectional variation in merger gains around M\&As, but only a limited number of papers study these effects in relation to real options (an exception is Agliardi et al. 2016). Our results provide an additional contribution to this debate. When we consider foreign target versus domestic target M\&As we find that, consistent with other studies, there is a higher takeover premia in foreign target than domestic target M\&As. Surprisingly, given the higher level of potential uncertainty in CBAs than domestic deals, there is no significant difference between CBA and domestic M\&As where the acquirer has an initial stake in the target or when they have 
positive return sensitivity.

In considering the possible joint effect of our two real option variables our results suggest that the pre-bid ownership reduces the takeover premia. Conversely, we find that real option intensive acquirers pay a higher premia for the real option intensive target. Combing these results, we argue that a real option intensive acquirer will pay higher premia to buy option-intensive target than to buy non-option intensive target, whereas the pre-bid ownership stake on the target seems to effectively moderate the higher takeover premia in the subsequent acquisition of the same target. Therefore, as we apply the real option arguments to both domestic and foreign target M\&As we add to the many papers on the determinants of the takeover premia in M\&As.

The remainder of this paper is organized as follows. In section 2 we discuss our real option measures and develop our research questions. Section 3 describes the data and the research method and section 4 presents our results. Finally, section 5 concludes the paper.

\section{Real Options Measures and Research Questions}

Before we outline our research questions, in this section we describe the real option measures that we use in our analysis based on time-to-build options and the growth opportunities in the like-buys-like setting.

\subsection{Real option measures}

\subsubsection{Time-to-build real options}

A time-to-build option reflects the flexibility of buying more time to better position a real 
investment decision such as entering a market or producing a good. ${ }^{6}$ It involves and depends on other firm specific, industry specific, as well as market-wide factors. The real option literature has focused on the modeling of time-to-build options. For instance, Majd and Pindyck (1987) explore the real option aspect in terms of time-to-build flexibility which takes advantage of new information arrival in a continuous fashion after the project begins. Subsequently, Milne and Whalley (2000) correct the time-to-build model of Majd and Pindyck (1987) by adding back the optimality condition in the analysis, which leads to the conclusion that a "naïve" NPV rule can sometimes be an appropriate initial guide to make investment decision. Similarly, Bar-Ilan and Strange (1998) construct a theoretical model for a two-stage sequential investment where time-to-build is considered. Agliardi and Koussis (2013) focus on the dynamic relationship between capital structure (i.e. the use of leverage) and the effect of time-to-build option on firm value. Their simulation result indicates that time-to-build has a significant impact on firm value for certain parameter values of debt choices.

Along these lines, Eckbo (2009) provides an extensive review of takeover studies including the effect of toehold strategies, which can be interpreted as an application of timeto-build option. Previous studies show that companies engaging in strategic alliances and joint ventures to acquire time-to-build real option to tackle environmental uncertainty and social uncertainty (Tong et al., 2008; McCarter et al., 2011). Acquirers obtain the time-tobuild option when they make partial acquisitions. Time-to-build option is embedded in investment projects in which firm choose a contingent plan for making sequential

\footnotetext{
${ }^{6}$ Time-to-build, reflecting the time it takes for the completion of a project, characterizes many investment decisions and exists at different intensities, depending on the industry the firm operates.
} 
expenditures by constantly learning from the new information (Majd and Pindyck, 1987). Acquirers are therefore gaining access to previously unavailable internal information by acquiring even a small number of shares of the target. As new information arrives and uncertainty about the cooperation prospects and market conditions are gradually resolved, acquirers may have the flexibility to halt, abandon or even expand its investments in the target company. Acquirers obtain the time-to-build real option by making the initial smaller investments (initial partial acquisition) and exercise the time-to-build real option by making sequential larger investments when the conditions are favorable (Li et al., 2007). Cheng, Heywood and Ye (2019) theoretically demonstrate that when the acquiring firm is domestic, a toehold can take place at any threshold for pricing control. However, if the acquirer is foreign, a toehold can be forestalled by a sufficiently high threshold. Such a threshold can improve domestic welfare and global welfare by stopping an inefficient partial acquisition. In the majority acquisitions, acquirers obtain the growth options of the target and hold more flexibility in deploying resources and developing new growth option with the target.

Uncertainty determines the value of time-to-build real options and further affects firms' decision of how much ownership to acquire and how they will expand acquisition sequentially (Folta and Miller, 2002; Kulatilaka and Perotti, 1998). We extend this argument in our first real option measure by examining how pre-bid ownership (similar to previous arguments on toehold stakes but without limiting the initial equity ownership to a small percentage as the term toehold implies) can be used by bidders to obtain real options to mitigate the information asymmetry before they launch a majority share acquisitions. We argue that bidders acquire time-to-build real option in pre-bid ownership and this initial ownership affects the takeover premia for subsequent acquisition of the target firm. 


\subsubsection{Growth opportunity, the like-buys-like setting, and real options}

Myers (1977) suggests that corporate assets, particularly growth opportunities, can be viewed as call options. In other words, the opportunity to invest in a project is analogous to an American call option on the investment opportunity. In fact, any opportunity with a choice whose value depends on an underlying asset can be viewed as an option (Geske, 1979). Some firms can enjoy growth opportunities but lack the capital required to realize those valuable investment projects. In other cases, firms with compatible technological capabilities can create synergistic value by combining these technological advantages. Under these situations, an acquisition can create value. By reallocating the capital and exercising the growth options, both companies can achieve growth after the acquisition. These 'financingmotivated 'acquisitions and like-buys-like mergers are very common in industries with emphasis on high-technology, R\&D and in innovative industries (e.g., computers and pharmaceuticals).

Bena and Li (2014) suggest that firms with technological overlap have a higher probability to be involved in M\&As. Extending this argument, the like-buys-like theory of M\&As suggests that firms would like to purchase targets with similar technological or growth characteristics. Therefore, like-buys-like mergers can result in a lower takeover premia as the target is a more willing seller and therefore accepts a lower premia. On the other hand, Bradley et al. (1988) argue that synergistic value is created in technological and innovative M\&As. In this case, it is possible for the acquirer to pay higher premia for the potential synergistic value.

Our second real option measure is based on this argument and allows us to capture 
managerial flexibility real options through the risk-return sensitivity. Grullon et al. (2012) show that technology and growth related real option level is reflected in the sensitivity of firm level stock return to volatility changes. ${ }^{7}$ They also show that a firm can benefit from upside business potential while reducing downside business risk through discretionary managerial flexibility. ${ }^{8}$ Therefore, if a firm has more real options, it is in a better position to take advantage of the higher volatility, leading to a bigger sensitivity of stock returns to volatility changes.

In short, when the firm has a number of real options, the sensitivity coefficient in the return-volatility regression is positive. However, when the firm does not hold any real option, the coefficient can be negative and the firm's return is mainly priced by risk factors. Therefore, to capture this growth opportunity in a like-buys-like setting, we identify merger pairs that both targets and acquirers possess real option capacity using the Grullon et al. (2012) method.

\subsection{Research questions}

We examine how real options affect the takeover premia in M\&As through two real option related characteristics, considering both domestic and foreign target M\&As. Following our

\footnotetext{
${ }^{7}$ The notion of viewing investment opportunities as growth options (i.e. real options) is initially outlined by Myers (1977). A number of papers have relied on this idea in subsequent empirical papers. For example, Grenadier (1996) explores the strategic exercise of real options using real estate data and Aguerrevere (2009) examines the linkage between real options, product market competition, and asset returns.

${ }^{8}$ With the control of downside risks and realization of favorable opportunities, firms can achieve a better performance with better managerial flexibility. For example, Grullon et al. (2012) compare real options of firms with and without labor unions. Their results show that due to managerial flexibility, non-unionized firms do demonstrate higher risk-return sensitivity (i.e., higher real option level) than the unionized counterparts. In addition to the operating flexibilities, there are some other forms of flexibility. Training and learning by doing create a more flexible workforce, and this flexibility constitutes a valuable real option. Similarly, at corporatewide level, gaining more know-how creates strategic competencies that are valuable (Merton, 1998). We suggest that possible applications of this learning real option could include buying a minority interest in the target before completing the acquisition.
} 
discussion above that strategic alliances and joint ventures are effective tools for companies to acquire time-to-build real options to tackle environmental and social uncertainty we extend this argument to the M\&As setting. We suggest that acquirers use pre-bid ownership to obtain time-to-build real option in order to mitigate environmental and social uncertainty in a full takeover. Betton and Eckbo (2000) suggest that the expected payoff to target shareholders decreases in the presence of the acquirer's toehold or initial ownership. We argue that this finding supports our real option conjecture that pre-bid ownership is a form of real option and the subsequent acquisitions as evidence of exercising such a real option. Consequently, we expect that our measure of pre-bid ownership as a form of time-to build real option is negatively related to the takeover premia. Therefore, our first hypothesis is stated as follows:

H1: The pre-bid ownership has a negative impact on the takeover premia.

For our second research question, we use Grullon et al. (2012) to suggest managerial flexibility and growth-related (like-buys-like) real options can be measured through firm level's sensitivity of return to volatility changes. The literature suggests that growth related and managerial flexibility could have a positive or negative impact on the takeover premia. However, we expect that if we have a positive real option measure based on firm level's sensitivity of return to volatility changes this should have a positive influence on the takeover premia. ${ }^{9}$ Therefore, in our second hypothesis is stated as follows:

\footnotetext{
${ }^{9}$ The leverage hypothesis would predict a negative relation, e.g., Black (1976) and Christie (1982). However, we follow Grullon et al. (2012) in providing an explanation for the positive contemporaneous relation between firm-level returns and firm-level volatility documented in Duffee (1995).
} 
H2: The real option of the merger pairs is positively related to the takeover premia.

\section{Data and Research Method}

\subsection{Data}

Our sample consists of completed pre financial crisis M\&As of US targets announced by US and non-US listed firms between 01/01/1985 and 31/12/2006 and recorded by the Security Data Corporation (SDC). In this period SDC records 59,318 M\&As involving US listed targets within the sample period. In order for a deal to remain in the sample, it must meet the following criteria: first, the acquirer and the target must be US or non-US listed firms and have a market value of at least $\$ 1 \mathrm{~m}$, measured 20 and 43 days prior to the announcement of the deal for the acquirer and the target, respectively. To avoid small deals, the transaction value needs to be at least $\$ 1 \mathrm{~m}$. Also, as we want to study M\&As clearly motivated by pre-bid ownership (which forms the real option that is exercised by subsequent acquisitions), we retain only deals for which we have the percentage of target shares acquired at the transaction, as well as the percentage of shares owned after the transaction. Deals for which the acquirers or the target are operating in regulated industry (Financials, Government and Agencies, and Energy and Power) are excluded for the sample. Buy-backs, repurchases, exchange offers, recapitalizations, privatizations, self-tender offers, spin-offs and reverse takeovers are excluded from the sample. To avoid the confounding effects of multiple deals, deals announced within 5-days surrounding another bid by the same acquirer are excluded from the sample. Furthermore, the daily stock price and market value of the acquirer need to be available from Datastream. Using this sample selection criteria results in a sample of 1,839 
where domestic (CBA) M\&As are 1,541 (298) of the deals.

\subsection{Research method}

\subsubsection{Estimation of premia}

We define the takeover premia as difference between the deal value and the market value of the target. The literature also shows that target share price start increasing before the announcement of a bid possibly due to the rumors of the deal (Schwert, 1996). To avoid possible implications of such rumors on the value of the target, we take the market value of the target 43 days prior to the date of the announcement of the deal. Moreover, to allow for the implication of partial acquisition on deal value we adjust for proportion of the shares acquired while estimating the premia. Hence, the premia (PREM) offered to the target firm in an M\&A is measured as in Equation (1):

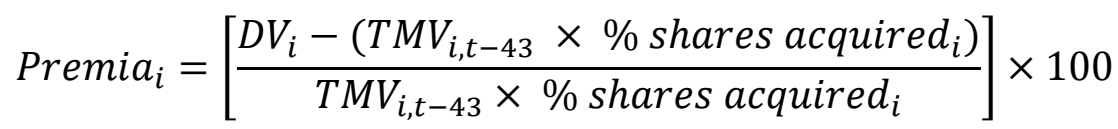

In equation (1) Premia $_{i}$ is the premia offered to the target firm in a deal, $D V_{i}$ is the deal value agreed between the acquirer and target firm and $T M V_{i}$ is the market value of target firm 43 days prior to the date of the announcement of the deal.

\subsubsection{Announcement period abnormal returns for acquirer and target firms}

In line with previous studies (Fuller et al., 2002; Barbopoulos and Sudarsanam, 2012) the short-run abnormal returns for an acquiring or target firm $i$, in response to a M\&A announcement, are estimated using the market-adjusted model, as shown in Equation (2):

$$
A R_{i, t}=R_{i, t}-R_{m, t}
$$


In equation (2) $A R_{i, t}$, is the abnormal return to acquirer or the target $i$ at day $t, R_{i, t}$ is the stock return of acquirer or target $i$ at day $t, R_{m, t}$ is the value-weighted market return index (the appropriate market index where the acquirer is listed, or the S\&P500 for the target) at day $t$. The announcement period Cumulative Abnormal Return (CAR) for acquirer $i$ is the sum of the abnormal returns in a 5-day window $(t-2$ to $t+2)$ surrounding the deal's announcement day, $t=0$. For target $i$, we use 23-day window ( $t-20$ to $t+2)$. The reasons are limited to the following arguments. We examine the $(t-20$ to $t+20)$ CARs for both bidders and targets. We observe that for bidders, no pre-event run-up and the market reaction can be captured well using a shorter 5-day event window (as in Fuller et al., 2002). However, for targets, it shows a possible information leakage or market rumor affecting the market reaction, leading to a run-up in CAR around 20 days before the announcement. Thus we choose a 23-day window for target in order to capture the whole reaction. The CAR calculation is shown in Equation (3):

$$
\operatorname{CAR}_{i}\left(T_{1}, T_{n}\right)=\sum_{t=T_{1}}^{T_{n}} A R_{i, t}
$$

where $T_{1}$ and $T_{n}$ are the first and last day of the event-window respectively, $A R_{i, t}$ is the abnormal return to acquirer or the target $i$ at day $t$ (as defined in equation 2).

\subsubsection{Regression model}

Following our arguments in section 3 we argue that the takeover premia can be explained as a function and interaction of three deal related characteristics, namely the prebid equity ownership, the firm's level risk return sensitivity of merger pairs, and the crossborder feature of the M\&As transaction. This is shown below in Equation (4). 


$$
\begin{aligned}
\text { Valuation }_{i, t}=\alpha_{i, t}^{1}+ & \alpha_{i, t}^{2} \text { PreOwn }_{i, t}+\alpha_{i, t-1}^{3} d 1_{i, t}+\alpha_{i, t-1}^{4} C B A_{i, t}+\alpha_{i, t}^{5} \text { PreO }_{i, t} \times C B A_{i, t}+\alpha_{i, t-1}^{6} d 1_{i, t} \times C B A_{i, t} \\
& +\alpha_{i, t-1}^{7} d 1_{i, t} \times C B A_{i, t} \times \text { PreOwn }_{i, t}+\sum_{j=8}^{k} \alpha^{j} \text { Controls }_{i, t}^{j}+\varepsilon_{i, t} \quad i=1 \ldots N
\end{aligned}
$$

where in equation (4): the valuation variable is measured as either the premia (as in equation 1) or the CAR (as in equation 3). Our two real option measures related to M\&As are pre-bid ownership (PreOwn), and secondly, based on the sensitivity of stock return to changes in volatility capturing the level of real option within a firm $(d 1)$. The real option measures and other variables (such as the acquirer location and other control variables) are explained in great detail in the next section (3.3) and are defined in Appendix 1.

\subsection{Real option measures, acquirer location and control measures}

\subsubsection{Real option measure - pre-bid ownership}

PreOwn is a dummy variable which is equal to one $($ PreOwn $=1)$ when acquirer has prebid ownership but not controlling interest, before the acquisition of the target and the acquirer takes control through the subsequent M\&As, and zero otherwise $($ PreOwn $=0)$. In this measure instead of measuring different types of real option directly, we infer the existence of real option through PreOwn.

\subsubsection{Real option measure - risk-return relation}

Based on Grullon et al. (2012), we argue that the positive relation between firm level stock return to changes in volatility is due to real options. The sensitivity of stock return to changes

in volatility captures the level of real option within a firm. In traditional asset pricing literature (Campbell and Hentschel, 1992), it is well established that contemporaneous returns are negatively correlated with volatility. One possible explanation for this negative 
relation is the 'leverage effect' hypothesis, which demonstrates that firms become more leveraged when the stock prices fall, leading to a higher volatility of stock returns. The other possible reason is that an increase in systematic volatility raises risk premia and expected future stock returns, and hence it reduces firm values, which result in the negative association between volatility and stock returns. In this paper, we use the sensitivity of stock return to changes in volatility to proxy for the firms' technology-related real option level. Following Grullon et al. (2012), the sensitivity of firm value to changes in volatility is estimated as follows in Equation (5):

$$
r_{i, \tau}-r_{f, \tau}=\alpha_{i, t}+\beta_{i, \tau}\left(r_{m, \tau}-r_{f, \tau}\right)+\gamma_{i, \tau} \Delta V O L_{i, \tau}+\varepsilon_{i, \tau}
$$

where: $r_{i, \tau}$ is firm level monthly stock return, $r_{f, \tau}$ is monthly risk free rate; $R_{m, t}$ is the valueweighted market return index (the appropriate market index where the acquirer is listed, or the S\&P500 for the target) at day $t$; volatility is calculated as the standard deviation of firm $i$ 's daily stock return during month $\tau$, and changes in volatility $\triangle V O L_{i, \tau}$ for firm $i$ in month $\tau$ is calculated as the difference between stock volatility in month $\tau$ and month $\tau-1$.

The real option level $\left(\gamma_{i, t}\right)$ is estimated as follows. For each firm $i$ in month $t$, we estimated the above time-series regression using data during months $\tau \in(t-71, t-$ 1). The estimated coefficient on $\triangle V O L_{i, \tau}, \gamma_{i, t}$ is the sensitivity of stock returns to changes in volatility, which serves as the measure of the individual firm's real option level. We use a dummy variable, $d 1$, to capture the like-buys-like merger motivation (Bena and Li, 2014) with growth related real options. We focus on M\&As where both the acquirer and target have positive values where $d 1$ equals to one $(d 1=1)$ when both acquirer and target have positive coefficients of the return-risk sensitivity, and zero otherwise $(d 1=0)$. 


\subsubsection{Acquirer location}

We argue that CBA can have higher uncertainty than domestic transactions due to potentially greater information asymmetries and cultural differences (see Barbopoulos et al., 2018). This uncertainty should strongly effect the takeover premia. Therefore, we include a dummy variable, which is assigned the value of $1(C B A=1)$ when the acquirer is a non-US firm, and the value of $0(C B A=0)$ when the acquirer is a US firm. Also to examine if an acquirer with real options could be willing to pay more for CBA, we also control for the possible joint effect of the two real option variables and the cross-border feature by various interaction terms (i.e. (a) PreOwn $\times C B A$; (b) $d 1 \times C B A$; (c) $d 1 \times C B A \times$ PreOwn).

\subsubsection{Control variables}

We include several known control variables from previous research that have shown to be strongly related to takeover premia, the impact of which is captured in the vector $\alpha^{j}$ (as in equation 4). We include dummy variables for the industry diversification $\left(D I V_{i}\right)$ (Denis et al., 2012; Erdorf et al., 2013), the method of payment $\left(\mathrm{CASH}_{i}\right)$ (Travlos, 1987; Chang and Mais, 2000), and a multiple bids dummy $\left(M B I D_{i}\right)$ (Servaes, 1991). We also include continuous variables for the acquirer size 20 days prior to the day of the M\&A announcement date $\left(\operatorname{Ln} A M V_{i, t-20}\right)$ and target size 43 days prior to the day of the M\&A announcement date $\left(\operatorname{LnTM} V_{i, t-43}\right)$ (Moeller et al., 2004), acquirer market-to-book value 20 days prior to the day of the M\&A announcement date $\left(A M T B V_{i, t-20}\right)$ and target market-to-book value 43 days prior to the day of the M\&A announcement date $\left(T M T B V_{i, t-43}\right)$ ), deal size $\left(\operatorname{LnDV} V_{i}\right)$ (Stulz et al., 1990), acquirer and target liquidity positions as measured by the acquirer and target cash ratio (cash \& cash equivalents over total assets) in the most recent financial statements, 
$\left(\right.$ ACASH_RATIO $_{i}$ and TCASH_RATIO $_{i}$, respectively) (Barbopoulos et al., 2018), acquirer and target leverage positions as measured based on the acquirer and target leverage ratio (debt over equity) in the most recent financial statements $\left(A L E V_{-} R A T I O_{i}\right.$ and $T L E V_{-} R A T I O_{i}$, respectively) (Barbopoulos et al., 2018) . More information on the definition of each variable and source of data can be found in Appendix 1.

\section{Results}

\subsection{Sample characteristics}

Table 1 illustrates the annual distribution of all, domestic, CBA with categories for focused, and diversifying deals, and by the payment method and pre-bid ownership. About 16\% (43\%) of the US listed targets are acquired by foreign (diversifying) acquirers. Cash payments dominate the acquisitions' financing method (42\%) with stock and mixed financing following with smaller fractions. Deals with pre-bid ownership represent about $16 \%$ of the sample. Figure 1 further demonstrates the time variation of the presence and absence of pre-bid ownership in our sample. It shows that M\&As with no pre-bid ownership tend to be higher than those with pre-bid ownership and increased significantly during the dot com merger wave.

(Insert Table 1 and Figure 1 about here)

For our real option estimation based on Grullon et al. (2012) (d1) (which accounts for $30 \%$ of the sample), this follows the merger and dot com merger waves. Table 1 shows the largest deals are announced during the dot com merger wave (1998 and 2002) and the highest takeover premia, as well as the highest abnormal returns gained by target shareholders, were observed during the same period. 
Table 2 shows that the higher premia are offered to US targets from foreign acquirers (63.84\%) rather from domestic ones (58.04\%). Similarly, the abnormal returns earned by target shareholders are higher from foreign (33.68\%) rather from domestic (28.86\%) deals. Higher premia is also offered in mixed financed deals (68.21\%), than in deals financed with the rest of payment methods. The level of pre-bid ownership is also found to be highly important in determining the premia offered to US targets. Specifically, the summary statistics identify a negative relation between the level of pre-bid ownership and premia, which is also true for target cumulative abnormal returns. To further explore how pre-bid ownership affect premia and abnormal returns for domestic versus CBA deals, we conduct a bivariate comparison in Panel B. For the first real option measure - pre-ownership (PreOwn), there are $14 \%$ (26\%) of domestic (foreign) deals with pre-bid ownership. These figures give a preliminary indication that in CBA deals the use of taking an initial stake is more frequent, supporting the suggestion that overseas acquisitions can be more challenging in terms of information asymmetry and regulatory hurdles.

For the real option measure, $(d 1)$, the merger pairs with positive real option for both targets and acquirers are larger for the CBA deals (38\%) in comparison to their domestic counterparts (29\%). We investigate this more fully in a multivariate framework in section 4.3.

(Insert Table 2 about here)

The summary statistics show that domestic deals are larger than CBA $(\$ 1,170 \mathrm{~m}$ deal value in domestic deals versus $\$ 918 \mathrm{~m}$ in foreign deals) while domestic acquirers are larger than foreign ones $(\$ 13,961 \mathrm{~m}$ market capitalization in domestic deals versus $\$ 10,999 \mathrm{~m}$ in foreign deals). In the context of focused versus diversifying deals, while the largest deals are 
the focused ones $(\$ 1,359 \mathrm{~m})$, the acquirers are larger in diversifying deals $(\$ 15,864 \mathrm{~m})$. Similarly, while mixed financed deals represent the largest ones $(\$ 1,768 \mathrm{~m})$ the largest acquirers are in cash financed deals $(\$ 16,767 \mathrm{~m})$.

Table 3 records the correlations between the variables in our analysis. Noticeable correlations, as expected, are recorded between Target MV and Deal Value (=96\%). As a result we ensure that we do not include both variables simultaneously in an estimation. The correlation coefficients in general do not raise any concerns regarding multicollinearity that may make it difficult to assess the effect of independent variables in multiple regressions.

(Insert Table 3 about here)

\subsection{Univariate analysis}

Table 4 reports the findings from our univariate analysis. It provides support to our first research question as pre-bid ownership (Yes PreOwn) is associated with a lower takeover premia (Higgins and Rodriguez 2006). Specifically, the differential premia between the No PreOwn and Yes PreOwn subsamples is statistically (at 1\% level) and economically (11.31\%) significant (Panel A). This pattern is clearly driven by domestic (Panel B1) deals as there is a relatively small insignificant difference in CBA (Panel C1). In terms of abnormal return earned by targets during the announcement period (Panels B2 and C2), domestic target CARs are $29.82 \%$ for No PreOwn and $22.92 \%$ for Yes PreOwn and CBA target CARs are $34.41 \%$ and $31.59 \%$ for No PreOwn versus Yes PreOwn. These CARs indicate that prebid ownerships results in a significant but smaller market reaction for both domestic and CBA deals. Also, CBA deals experience a bigger market reaction than the domestic one. Finally, the bidder CARs exhibit some interesting implications (Panels B3 and C3). First, domestic 
bidders receive a negative and significant CAR for No PreOwn but a close to zero CAR for Yes PreOwn, resulting in a negatively significant difference in CAR for the two subgroups. On the other hand, for CBA deals, bidders with No PreOwn get a small but positively significant CAR and Yes PreOwn bidders experience a larger significant positive market reaction. Also the differential CAR is significant. This is interesting as the literature generally concludes that bidders receive zero or slightly negative announcement effect for M\&As (Jensen and Ruback, 1983). In this paper, we observe a significantly positive CAR for CBA bidders, especially for Yes PreOwn bidders.

(Insert Table 4 about here)

\subsection{Multivariate analysis}

Table 5, Panel A, reports our main findings based on our regression model as defined in equation 4. Models (1) to (4) in Table 4 (Panel A) shows the regression results using Premia (as dependent variable) as the measure of takeover premia (as in equation 1). Yes PreOwn is negative and statistically significant at the $1 \%$ level across all four models, indicating that pre-bid ownership enables the acquirer to pay a lower premia in a subsequent acquisition. This is consistent with our first hypothesis predicting that the pre-bid ownership serves as a form of time-to-build a real option (consistent with Betton and Eckbo, 2000). In particular, as the pre-bid ownership enables the acquirer to potentially (a) gain privileged information of the target firm's business operations through pre-bid ownership, and (b) familiarity with the target management, the acquirer can improve the success of the current acquisition by negotiating a better/accurate acquisition price that results in a lower takeover premia.

(Insert Table 5 about here) 
In testing our second hypothesis, we expect our second real option proxy (d1) for both acquirer and target to have a positive sensitivity of return to volatility changes. Models (1) to (4) (Panel A) show positively significant coefficients of $d 1$ at the $5 \%$ level $(10 \%$ level in Model (4)). This result supports the view that when both acquirer and target contain growth related options, they offer a higher takeover premia which is potentially reflecting the higher merger synergies. Consequently, an acquirer with real options is willing to pay a higher takeover premia for real option-embedded target, supporting our second hypothesis. Therefore, following Grullon et al (2012), the argument is that a real option's value is increasing in volatility of an underlying process, and thus if real options are an important factor in firm values, then the latter should also be positively related to volatility.

Models (1) to (4) (Panel A) also show a significant positive relation between CBA and the takeover premia. This is consistent with previous evidence that CBA offer a higher takeover premia to targets than domestic M\&As. However, when we interact CBA with prebid ownership, it is no longer significant, possibly indicating that the uncertainty that is usually present in CBA is reduced by the information gained by holding a prior stake. Secondly, the real option has a higher value when information uncertainty is stronger which would typically be the case is for CBA (Harris and Ravenscraft, 1991). Lastly, our second option proxy $(d 1)$ is negatively related to the takeover premia if we interact with CBA but it is not significant.

We deal with concerns related to the potentially endogenous firm's choice to diversify internationally or not (i.e., CBA) by including the Inverse Mills Ratio (IMR) in our regressions. Specifically, the IMRs are associated with the selection equations that correspond to the firm's choice to globally diversify (i.e., CBA). We therefore use a bivariate probit model with 
sample selection to control for self-selection for the decision of CBA. For brevity, we do not report the parameters from the first stage (selection, or first stage) equation and also the parameters from the output (second stage) equation. ${ }^{10}$ Table 4, Panel B, records only the CBA coefficient, as well as the IMR or $\lambda_{C B A}$ coefficient in the Heckman treatment model (second stage equation). In Model (1) (Panel B) the coefficient on the cross-border indicator (CBA) is (8.394) is slightly smaller than the equivalent CBA coefficient in Model (1) (Panel A) and significant at the $1 \%$ level, and Lambda $\left(\lambda_{C B A}\right)$ is negative and also statistically significant $(-117.829)$. As the parameters of cross-border indicators in both Panels A and B appear similar our initial model (Panel A) could be underestimating the cross-border effect. Therefore factors influencing the foreign M\&A could be negatively associated with the takeover premia. Similar effects are recorded across Models (2) to (4).

We also consider the target and acquirer short-run market reaction to the M\&A announcement as the dependent variable in each of the Models (5) to (12). In particular, in Models (5) to (8) (Table 5) the dependent variable is the target CAR while in Models (9) to (11) (Table 5) the equivalent is the acquirer CAR. A rich array of studies confirm that M\&As are largely wealth-increasing for the shareholders of the target firms, but they are mostly wealth-destroying, or at best wealth-neutral, for the shareholders of acquirers (see Andrade et al., 2001; Eckbo, 2009). Similar to our results for the takeover premia, in Models (5) to (8)

\footnotetext{
${ }^{10}$ The variables in the selection equation are (a) dummy variable indicating the presence of toehold, (b) d1 as the real option dummy (c) dummy variable indicating the presence of diversifying deal, (d) log of acquirer and target market value 20 and 43 days prior to the deal's announcement day, respectively, (e) acquirer and target market-to-book value 20 and 43 days prior to the deal's announcement day, respectively, (f) acquirer and target cash ratio (= ratio of cash and equivalents to total assets) in the most recent financial reporting to the deal's announcement day, (g) acquirer and target debt-to-equity ratio (= ratio of debt to equity), (h) dummy variable indicating multiple bidders, (i) dummy variable indicating the presence of cash financed deals, and (j) time and target-industry fixed effects. The variables in the output equation are the same to those entering the selection equation, in addition to the CBA dummy that indicates the presence of foreign deal. Panel (B) of Table (5) report CBA and IMR $\left(\lambda_{C B A}\right)$ coefficients.
} 
Yes PreOwn is significantly negative at $1 \%$ level, indicating that pre-bid ownership (having a real option) is negatively related to the market reaction of the target firm. As discussed earlier in the paper, this is consistent with our conjecture that the pre-bid ownership reduces the information asymmetry in the M\&A and increases the familiarity of the acquirer management with the target management. Therefore the price paid for the target is more reflective/accurate of the value of the target, which is ultimately reducing the gains to target shareholders due to lower takeover premia. We also find a positive and significant relation (at 1\% level) between the target CAR and our second option proxy ( $d 1$ ) in Models (5) to (8), indicating that targets enjoy a positive market reaction when both merging firms possess real options or growth related options. Our results also show that, collectively, CBA is only marginally significant in the Models (5), (7) and (8) and the interaction variables between our real option measures and CBA are insignificant (with the exception of Model (7) where it is negative and marginally statistically significant). Moreover, in Model (5) (Panel B) the coefficient on the cross-border indicator is (2.707) is slightly smaller than the CBA equivalent coefficient in Model (5) (Panel A), yet statistically insignificant, and Lambda $\left(\lambda_{C B A}\right)$ is negative and statistically significant (-57.729). Once again, although the parameters of crossborder indicators appear similar (across Panels A and B), our initial model (Panel A) could be underestimating the cross-border effect, since factors influencing the foreign deal decision appear to be negatively associated with the target CAR. Lasty, similar effects are recorded in Models (6) to (8) (across both panels A and B).

Consistent with the negative relation between the target firm's CAR and the acquirer pre-bid ownership in Models (5) to (8), there is a significant positive reaction of the acquirer CAR in Models (9) to (12) given the acquirer pre-bid ownership in the target. Therefore, 
despite the overwhelming evidence from the literature that acquirer returns are mostly negative, the market reaction is positive when the acquirer has a prior ownership stake. This is consistent with our argument that the market views the pre-bid ownership as a value creating/adding element for the acquirer through the channel of cheaper purchase price offered to the target. We also find significant relation (mainly at $5 \%$ level) between acquirer CAR and our second option proxy ( $d 1)$ in Models (9) to (12), indicating that acquirers enjoy a positive market reaction when both merging firms possess real options or growth related options. In addition, CBA is significant in the Models (9) and (12) and the interaction variables between our real option measures and CBA are mainly insignificant (except in Model (12) where it is negative and marginally statistically significant). Lastly, in Model (9) (Panel B) the coefficient on the cross-border indicator is (1.022) is slightly smaller than the equivalent CBA coefficient in Model (9) (Panel A) and significant at the 5\% level, while Lambda is positive and marginally statistically significant (7.228). While parameters of cross-border indicators appear similar (across Panels A and B), our initial model (Panel A) could be weakly overestimating the cross-border effect, since factors influencing the foreign deal appear to be positively associated, yet marginally statistically significant, with the acquirer CAR. Similar effects are recorded across the Models (10) to (12) (across both panels A and B).

The significance of our control variables in Table 5 are generally consistent with the literature. There is mixed prior evidence on acquirer market reaction to CBA announcements. ${ }^{11}$ We find that in Models (9) to (12) that the acquirer market reaction is

\footnotetext{
${ }^{11}$ Francis et al. (2008) find positive acquirers' value gains surrounding announcements of CBA, but Gregory and McCorriston (2005) suggest there are no gains to acquirers.
} 
positive for CBA (purchases of US targets). The significantly negative relationship between target size ( $\left.\operatorname{Ln}\left(T M V_{t-43}\right)\right)$ and premia (Models (1) to (4)) or target CAR (Models (5) to (8)) indicate that larger targets receive lower premia. ${ }^{12}$ This is possibly due to lower merger synergies due to more difficult integration process between the merging firms, in particular when the target is a large firm. The coefficient for $M B I D$ is generally statistically insignificant across all Models, which suggests that multiple bidders do not bid up the price for acquiring the target. As we control for the presence of pre-ownership of the acquirer in the target, the insignificant coefficient of $M B I D$ might be due to the presence of more information in the deal's process (as explained earlier in the paper) and hence the lack of aggressive bidding behavior. The coefficient for $C A S H$ is significantly negative in Models (1) to (4) and positive in Models (5) to (12). For Models (1) to (4) this supports the prediction that targets shareholders prefer cash and are willing to accept a smaller premia for cash deals relative to stock and mixed deals. The literature offers several contradicting perspectives on payment methods in $M \& A s^{13}$ and we find that the market reaction to both the acquirer and the target is positive in cash deals. Among other potential explanations, the acquirer stock overvaluation could be associated with the higher market perception of cash financed deals, as reflected on the positive cash financed coefficient across Models (5) to (12). ${ }^{14}$

\footnotetext{
12 There is also a negative market reaction for the acquirer in Models (9) to (12) based on the target size $\left(\operatorname{Ln}\left(T M V_{t-43}\right)\right)$.

${ }^{13}$ For example, Lin, Chou, and Cheng (2011) conclude that the magnitude of pre-acquisition misvaluation of the acquiring firm drives post-acquisition underperformance for stock deals.

${ }^{14}$ We have also tested whether conglomerate and horizontal mergers, as well as complementary resources merges, explain a greater variation of premia and target or acquirer CAR. Our results show that there is an insignificant effect. This is possibly due to the fact that the uncertainty embedded in different types of M\&As is reduced by the information gained by holding a prior stake or growth-related options. Hence, when controlling for the presence of a real option, the effects of conglomerate, horizontal and complementary mergers remain insignificant.
} 


\subsection{Robustness checks}

\subsubsection{The real option in $M \& A s$}

To provide evidence that our real option argument based on the Grullon et al. (2012) framework exists in the M\&A setting, we provide some additional empirical analysis which we suggest it helps to provide support to the findings in this paper..$^{15}$ We follow exactly the estimation procedure and the real option analysis in Grullon et al. (2012) for a sample US M\&As from 1977 to 2014. After matching with additional financial data three years after the merger until 2014 to estimate post-merger real options, our sample has 4,315 deals. We find that firm level real options as reflected by positive regression coefficients do exist in our M\&A sample as the real option proxies are significant and positively correlated with firm-level excess return. Next, we find that our real option proxy is positively correlated with various measures of investment (growth) opportunities and the classification of option-intensive industries for the acquirers by Grullon et al. (2012). This result indicates that the positive return-volatility relationship is stronger for firms in real option-intensive industries. To examine the time-series evolution of real options, we check whether the positive relation is expected to be weakened following events of real option exercise. From Year - 3 to Year -1 we find that that real option level has reduced during this period. On the other hand, the target sample shows a relatively stable pattern during the same pre-merger period. More importantly, the coefficient for the targets one year prior to the merger (year -1) is significantly larger than that for the acquirers, indicating that the targets show a much higher real option level than the that of the acquirers immediately before the merger. Therefore we

\footnotetext{
${ }^{15}$ For brevity we have not included this analysis in the paper but the tables are available on request from the
} authors. 
suggest that acquirers suffer from a steady decline of real option during the pre-event years. Thus the acquirers are motivated to seek external injection of real option through M\&As.

In addition, in identifying the appropriate targets, it is reasonable for the acquirers to choose targets with a stable (instead of declining) and, more importantly higher level of real option. To further support our real option argument for M\&As, we turn to the pre- and postevent comparison of real option level for the acquirers. From year -1 to year +1 , the returnvolatility coefficients for acquirers drop significantly. On the other hand, the return-volatility coefficients for the control group remain stable and high for the post-event years. These findings are consistent with Grullon et al. (2012), and suggests that firms exercise most of their real option through investing.

To examine if that the significant drop of the coefficient is related to investment spike. We check the real investment rate changes of the acquiring firms immediately after the M\&A event. We find that the acquirers' investment rate (measured as the M\&A transaction value divided by total assets) is on average $17.03 \%$. This rate is significantly larger than the peer firms' 5.81\% investment rate for the same year (consistent when using different peer benchmarks). We can therefore conclude that the decline on the real options of the acquirers is associated with a corresponding increase in real investments. This finding is consistent with our conjecture that the acquirers exercise real option through the acquisitions. In order to show that the declination of acquirers' coefficients in the prior merger period and the significant difference between acquirers' and targets' coefficients are not random effects, we further conduct a placebo test which indicates that the real option results are unique for M\&A firms. In conclusion, we suggest that this analysis demonstrates that the real option argument we have does exist empirically in M\&A activities. 


\subsubsection{Alternative event window}

In Table 5 we use the event window $(t-20, t+2)$ for the target CAR and the event window $(t-2, t+2)$ for the acquirer CAR. For the target CAR, the window $(t-20, t+2)$ could be problematic due to problems with the share price increases prior to the announcement of the M\&As. To avoid this issue, we use various windows of target CAR, $(t-10, t+2),(t-$ $5, t+2)$, and $(t-1, t+1)$. For the acquirer CAR the established window in the literature is $(t-2, t+2)$ (see Fuller et al., 2002). However, we also use various windows $[(t-10, t+$ 10), $(t-10, t+5),(t-10, t+2),(t-5, t+5),(t-5, t+2),(t-1, t+1)]$ to confirm our main findings. In these alternative estimations (results are not reported but are available upon request from the authors) using the above windows for both the acquirer and target CAR, our results in Table 5 are quantitatively the same.

\section{Conclusion}

The contribution of this paper is that we apply real option arguments to understand the possible determinants of the takeover premia in M\&As. We examine the extent to which real options affect the takeover premia in M\&As through two deal and firm related characteristics: (a) pre-bid ownership, and (b) firm level risk-return sensitivity of merger-pairs. Firstly, we argue that pre-bid ownership is a form of real option purchased by the acquirer which can be exercised through a subsequent M\&As transaction. The cost of the option is the percentage of the shares purchased initially. This real option allows the potential acquirers to gain access to privileged information and familiarity with senior management/decision makers in the target firm. This reduces the information asymmetry between the acquirer and target and 
uncertainty in the post-acquisition value. If the acquirer decides to proceed with the full acquisition of the target (exercise their option). The familiarity with the target allows the acquirer to 'negotiate' a lower takeover premia and the reduction in uncertainty can mean that the offer price is more reflective of the true value of the target.

Our first result supports this view, as we find that the takeover premia is lower for completed M\&As, where there was a prior ownership stake. This argument is further supported when we measure the takeover premia as the target market reaction to the announcement, as contrary to the common finding that target shareholders benefit in the M\&As, we find the target market reaction is lower in deals in which there is a pre-bid ownership of the target by the acquirer. This indicates that the market views the takeover premia to be reflective of the value of the target and reduces the gains to target shareholders.

Secondly, based on positive risk-return sensitivity as our second real option proxy (Grullon et al., 2012) and the like-buys-like argument on firm level innovations (Bena and Li, 2014) in merger incidence, we find that offer premia is higher when both the acquirer and target exhibit positive risk-return sensitivity. Consistent with the like-buys-like argument, the acquirer with real option is willing to pay a higher takeover premia for these optionembedded targets. Combing these results, we conclude that a real-option intensive acquirer will pay higher premia to buy option-intensive target than to buy non-option intensive target, but pre-bid ownership stake effectively more than offsets the higher takeover premia in the subsequent acquisition of the target.

These results provide evidence of real options having an impact on the takeover premia offered to targets in M\&As. As CBAs have higher uncertainty than domestic transactions due to potentially greater information asymmetries and cultural differences, we also control for 
the possible joint effect of these two real option variables in CBA versus domestic deals. We find that there is a higher takeover premia in CBA than domestic M\&As, but there is no significant difference between CBA and domestic M\&As when we include whether the acquirer has an initial stake in the target.

Overall our results suggest that there is a clear role for real options in understanding the takeover premia in M\&As. To develop this further, future research should consider different levels in prior ownership as a measure of the real option. Also the sample could be developed to consider international targets where there could be greater information asymmetry and cultural differences between the acquirers and targets. 
Appendix 1 Variable definitions

\begin{tabular}{|c|c|c|c|}
\hline Variable & Acronym & Description & Source \\
\hline Domestic & DOM & Dummy=0 if both firms are US. & SDC \\
\hline $\begin{array}{l}\text { Cross-Border } \\
\text { Acquisition }\end{array}$ & $C B A$ & $\begin{array}{l}\text { Dummy }=1 \text { if the Acquirer is a non-US firm and the Target } \\
\text { is a US firm. }\end{array}$ & SDC \\
\hline Diversified/Focused & DIV/FOC & $\begin{array}{l}\text { Dummy=1 when the acquirer and target do not share the } \\
\text { same } 2 \text {-digit code and Dummy=0 when the acquirer and } \\
\text { target share the same } 2 \text {-digit code (=FOC). }\end{array}$ & SDC \\
\hline $\begin{array}{l}\text { Cash Financed } \\
\text { Transactions }\end{array}$ & $\mathrm{CASH}$ & $\begin{array}{l}\text { Dummy }=1 \text { if the consideration is } 100 \% \text { financed with } \\
\text { cash and Dummy }=0 \text { otherwise. }\end{array}$ & SDC \\
\hline $\begin{array}{l}\text { Stock Financed } \\
\text { Acquisitions }\end{array}$ & STOCK & $\begin{array}{l}\text { Dummy }=1 \text { when the consideration is } 100 \% \text { financed } \\
\text { with stocks and Dummy=0 otherwise. }\end{array}$ & SDC \\
\hline $\begin{array}{l}\text { Transactions financed } \\
\text { with a mixture of cash } \\
\text { and stock }\end{array}$ & MIXED & $\begin{array}{l}\text { Dummy = } 1 \text { when the deal is financed with a mixture of } \\
\text { cash and stock and Dummy=0 otherwise. }\end{array}$ & SDC \\
\hline No Pre-bid ownership & $\begin{array}{l}\text { No-Preown } \\
\text { (NPO) }\end{array}$ & No pre-bid ownership prior to completed M\&A & SDC \\
\hline Pre-bid ownership & $\begin{array}{l}\text { Yes-Preown } \\
\text { (YPO) }\end{array}$ & Pre-bid ownership present prior to $M \& A$. & SDC \\
\hline Pre-bid Ownership & PreOwn & $\begin{array}{l}\text { Dummy which equals } 1 \text { if pre-bid ownership exists } \\
\text { before M\&A and } 0 \text { otherwise }\end{array}$ & SDC \\
\hline Real option Dummy & $d 1$ & $\begin{array}{l}\text { Dummy=1 if both acquirer and target real option } \\
\text { coefficient is positive, and Dummy=0 otherwise (real } \\
\text { option as captured by } r_{i, \tau} \text { in equation } 5 \text {. For more } \\
\text { information see section } 3.3 .2 \text { ). }\end{array}$ & $\begin{array}{l}\text { Grullon et al. } \\
\text { (2012) \& Eq. } 5\end{array}$ \\
\hline Deal Value & $D V$ & Reported deal value, in millions of dollars. & SDC \\
\hline $\begin{array}{l}\text { Premia Offered to the } \\
\text { Target }\end{array}$ & PREM & $\begin{array}{l}\text { refers to the acquisition premia based on Equation (1), } \\
\text { section 3.2.1 }\end{array}$ & $\begin{array}{l}\text { Datastream \& } \\
\text { SDC }\end{array}$ \\
\hline $\begin{array}{l}\text { Cumulative Abnormal } \\
\text { Returns }\end{array}$ & CAR & $\begin{array}{l}\text { The sum of the acquirer's }(A C A R) \text { or target's }(T C A R) \\
\text { abnormal returns in the specified window surrounding } \\
\text { the announcement. }\end{array}$ & $\begin{array}{l}\text { Datastream \& } \\
\text { SDC }\end{array}$ \\
\hline $\begin{array}{l}\text { Target cumulative } \\
\text { abnormal return (CAR) }\end{array}$ & TCAR & refers to target $C A R(t-20, t+2)$, in $\%$. & $\begin{array}{l}\text { Datastream \& } \\
\text { SDC }\end{array}$ \\
\hline $\begin{array}{l}\text { Acquirer cumulative } \\
\text { abnormal return (CAR) }\end{array}$ & ACAR & refers to acquirer $C A R(t-2, t+2)$, in $\%$. & $\begin{array}{l}\text { Datastream \& } \\
\text { SDC }\end{array}$ \\
\hline $\begin{array}{l}\text { Market Value of the } \\
\text { Target's Equity }\end{array}$ & $T M V$ & $\begin{array}{l}\text { Target's market value of equity at } 43 \text { trading days prior } \\
\text { to bid announcement, in millions dollars. We also employ } \\
\text { the natural logarithm of this variable. }\end{array}$ & Datastream \\
\hline $\begin{array}{l}\text { Market Value of the } \\
\text { Acquirer's Equity }\end{array}$ & $A M V$ & $\begin{array}{l}\text { Acquirer's market value of equity at } 20 \text { trading days prior } \\
\text { to bid announcement, in millions dollars. We also employ } \\
\text { the natural logarithm of this variable. }\end{array}$ & Datastream \\
\hline Acquirer cash ratio & ACASH_RATIO & $\begin{array}{l}\text { Acquirer's ratio of total cash and cash equivalents to total } \\
\text { assets in the quarter prior to the announcement of the } \\
\text { deal. }\end{array}$ & Datastream \\
\hline Acquirer debt/equity & $A L E V_{-} R A T I O$ & $\begin{array}{l}\text { Acquirer's total debt as a percentage of common equity } \\
\text { value during the quarter prior to the announcement of } \\
\text { the deal. }\end{array}$ & Datastream \\
\hline $\begin{array}{l}\text { Acquirer Market-to- } \\
\text { Book Value }\end{array}$ & AMTBV & $\begin{array}{l}\text { Acquirer's ratio of market value over book value of equity } \\
\text { (measured } 20 \text { days prior to the deal's announcement). }\end{array}$ & Datastream \\
\hline Target cash ratio & TCASH_RATIO & $\begin{array}{l}\text { Target's ratio of total cash and cash equivalents to total } \\
\text { assets in the quarter prior to the announcement of the } \\
\text { deal. }\end{array}$ & Datastream \\
\hline Target debt/equity & TLEV_RATIO & $\begin{array}{l}\text { Target's total debt as a percentage of common equity } \\
\text { value during the quarter prior to the announcement of } \\
\text { the deal. }\end{array}$ & Datastream \\
\hline $\begin{array}{l}\text { Target Market-to-Book } \\
\text { Value }\end{array}$ & TMTBV & $\begin{array}{l}\text { Target's ratio of market value over book value of equity } \\
\text { (measured } 43 \text { days prior to the deal's announcement). }\end{array}$ & Datastream \\
\hline Multiple bidders & MBID & $\begin{array}{l}\text { Dummy }=1 \text { if the number of bidders is more than } 1 \text {, and } \\
\text { Dummy }=0 \text { otherwise. }\end{array}$ & Datastream \\
\hline
\end{tabular}




\section{References}

Agliardi, E. and Koussis, N. (2013). Optimal capital structure and the impact of time-to-build. Finance Research Letters, 10, 124-130.

Agliardi, E., Amel-Zadeh, A., and Koussis, N. (2016). Leverage changes and growth options in mergers and acquisitions. Journal of Empirical Finance, 37, 37-58.

Aguerrevere, F. L. (2009). Real options, product market competition, and asset returns. The Journal of Finance, 64(2), 957-983.

Amihud, Y., and Lev, B. (1981). Risk reduction as a managerial motive for conglomerate mergers. The Bell Journal of Economics, 12(2), 605-617.

Andrade, G., Mitchell, M., and Stafford, S. (2001). New evidence and perspectives on mergers, Journal of Economic Perspectives, 15, 103-120.

Bar-Ilan, A. and Strange, W.C. (1998). A model of sequential investment. Journal of Economic Dynamics and Control, 22, 437-463.

Barbopoulos, L., and Sudarsanam, S. (2012). Determinants of earnout as acquisition payment currency and bidders' value gains. Journal of Banking and Finance, 36, 678-694.

Barbopoulos, L.G., Danbolt, J., and Alexakis D. (2018). The role of earnout financing on the valuation effects of global diversification. Journal of International Business Studies, 49, 523-551.

Bena, J., and Li, K. (2014). Corporate innovations and mergers and acquisitions. The Journal of Finance, 69(5), 1923-1960.

Betton, S., and Eckbo, B. E. (2000). Toeholds, bid jumps, and expected payoffs in takeovers. Review of Financial Studies, 13(4), 841-882.

Bjerksund, P., and Ekern, S. (1990). Managing investment opportunities under price uncertainty: From "last chance" to "wait and see" strategies. Financial Management, 19(3), 65-83.

Black, F. (1976). The pricing of commodity contracts. Journal of Financial Economics, 3, 167179.

Bradley, M., Desai, A., and Kim, E.H. (1988). Synergistic gains from corporate acquisitions and their division between the stockholders of target and acquiring firms. Journal of Financial Economics, 21(1), 3-40.

Bruner, R.F. (2004). Applied mergers and acquisitions (Vol.173). John Wiley \& Sons.

Campbell, J.Y., and Hentschel, L. (1992). No news is good news: An asymmetric model of changing volatility in stock returns. Journal of Financial Economics, 31(3), 281-318.

Chang, S., and Mais, E. (2000). Managerial incentives and merger financing. The Financial Review, 35(4), 139-152.

Cheng, L., Heywood, J.S., and Ye, G. (2019). Partial acquisition with an excluded public rival. International Review of Economics and Finance, 59, 164-173.

Christie, A. A. (1982). The stochastic behavior of common stock variances: Value, leverage and interest rate effects. Journal of financial Economics, 10(4), 407-432.

Copeland, T.E., and Antikarov, A. (2001). Real options: a practitioner's guide. Texere, New York, NY.

Denis, D. J., Denis, D. K., and Yost, K. (2002). Global diversification, industrial diversification, and firm value. The Journal of Finance, 57(5), 1951-1979.

Duffee, G. (1995). Stock return and volatility: A firm-level analysis. Journal of Financial Economics, 37(3), 399-420. 
Eckbo, B.E. (2009). Bidding strategies and takeover premiums: A review. Journal of Corporate Finance, 15(1), 149-178.

Erdorf, S., Hartmann-Wendels, T., Heinrichs, N., and Matz, M. (2013). Corporate diversification and firm value: a survey of recent literature. Financial Markets and Portfolio Management, 27, 187-215.

Folta, T.B., and Miller, K.D. (2002). Real options in equity partnerships. Strategic Management Journal, 23(1), 77-88.

Francis, B.B., Hasan, I., and Sun, X. (2008). Financial market integration and the value of global diversification: Evidence for US acquirers in cross-border mergers and acquisitions. Journal of Banking and Finance, 32, 1522-1540.

Fuller, K., Netter, J., and Stegemoller, M. (2002). What do returns to acquiring firms tell us? Evidence from firms that make many acquisitions. Journal of Finance, 57, 1763-1793.

Geske, R. (1979). A note on an analytical valuation formula for unprotected American call options on stocks with known dividends. Journal of Financial Economics, 7(4), 375-380.

Gregory, A., and McCorriston S. (2005). Foreign acquisitions by UK limited companies: shortand long-run performance. Journal of Empirical Finance, 12, 99-125.

Grenadier, S.R. (1996). The strategic exercise of options: development cascades and overbuilding in real estate markets. The Journal of Finance, 51(5), 1653-1679.

Grullon, G., Lyandres, E., and Zhdanov, A. (2012). Real options, volatility, and stock returns. The Journal of Finance, 67 (4), 1499-1537.

Harris, R.S., and Ravenscraft, D. (1991). The role of acquisitions in foreign direct investment: Evidence from the US stock market. The Journal of Finance, 46(3), 825-844.

Higgins, M. J., and Rodriguez, D. (2006). The outsourcing of R\&D through acquisitions in the pharmaceutical industry. Journal of Financial Economics. 80 351-383.

Huizinga, H., Voget, J., and Wagner, W. (2012). Who bears the burden of international taxation? Evidence from cross-border M\&As. Journal of International Economics 88, 186197.

Jensen, M. C., and R. S. Ruback. (1983). The market for corporate control: The scientific evidence. Journal of Financial Economics 11, 5-50.

Kogut, B., and Kulatilaka, N. (1994). Operating flexibility, global manufacturing, and the option value of a multinational network. Management Science, 40(1), 123-139.

Kulatilaka N., and Perotti, E.C. (1998). Strategic growth options, Management Science, 44(8), 1021-1031.

Li, Y., James, B., Madhavan, R., and Mahoney, J.T. (2007). Real options: taking stock and looking ahead. Advances in Strategic Management, 24(1), 31-66.

Lin, H.C., Chou T.K., and Cheng, J.C. (2011). Does market misvaluation drive post-acquisition underperformance in stock deals?. International Review of Economics and Finance, 20, 690-706.

Majd, S., and Pindyck, R.S. (1987). Time to build, option value, and investment decisions. Journal of Financial Economics, 18(1), 7-27.

McCarter, M.W., Mahoney, J.T., and Northcraft, G.B. (2011). Testing the waters: using collective real options to manage the social dilemma of strategic alliances. Academy of Management Review, 36(4), 621-640.

Merton, R.C. (1998). Applications of option-pricing theory: twenty-five years later (Digest Summary). American Economic Review, 88(3), 323-349.

Milne, A., and Whalley, A.E. (2000). Time to build, option value and investment decisions: a 
comment. Journal of Financial Economics, 56, 325-332.

Mitchell, G.R., and Hamilton, W.F. (1988). Managing R\&D as a strategic option. Research Technology Management, 31(3), 15-22.

Moeller, B.S., and Schlingemann, P.F. (2005). Global diversification and acquirer gains: a comparison between cross-border and domestic acquisitions. Journal of Banking and Finance, 29, 533-564.

Moeller, B.S., Schlingemann, P.F., and Stulz, M.R. (2004). Firm size and gains from acquisitions. Journal of Financial Economics, 73, 201-228.

Morck, R., Schwartz, E., and Stangeland, D. (1989). The valuation of forestry resources under stochastic prices and inventories. Journal of Financial and Quantitative Analysis, 24 (4), 473-487.

Myers, S.C. (1977). Determinants of corporate borrowing. Journal of Financial Economics, 5, 147-175.

Pereira, P.J., and Rodrigues, A. (2019). Bargaining merger terms and the effect on the announcement returns. International Review of Economics and Finance, 59, 510-521.

Rossi, S., and Volpin, P.F. (2004). Cross-country determinants of mergers and acquisitions. Journal of Financial Economics, 74(2), 277-304.

Schwartz, E.S., and Trigeorgis, L. (2001). Real options and investment under uncertainty: Classical readings and contributions, MIT Press.

Schwert, G.W. (1996). Markup pricing in mergers and acquisitions. Journal of Financial economics, 41(2), 153-192.

Servaes, H. (1991). Tobin's Q and the gains from takeovers. Journal of Finance, 46, 409-419.

Seth, A., Song, K.P., and Pettit, R.R. (2002). Value creation and destruction in cross-border acquisitions: an empirical analysis of foreign acquisitions of US firms. Strategic Management Journal, 23(10), 921-940.

Shibata, T., and Wong, P.T. (2019). Investment under uncertainty with variable costly reversibility. International Review of Economics and Finance, 59, 14-28.

Smith K.W., and Triantis, A.J. (1995). The value of options in strategic acquisitions. In Real Options in Capital Investment, Trigeorgis L (ed). Greenwood Publishing Group, Praeger: Westport, CT; 135-149.

Stulz, R.M., Walkling, R.A. and Song, M.H. (1990). The distribution of target ownership and the division of gains in successful takeovers. Journal of Finance, 45, 817-33.

Sudarsanam, S. (2010). Creating value from mergers and acquisitions: The challenges (Pearson Education Limited, London).

Tong, T.W., Reuer, J.J., and Peng, M.W. (2008). International joint ventures and the value of growth options. Academy of Management Journal, 51(5), 1014-1029.

Travlos, N.G. (1987). Corporate takeover bids, method of payment, and bidding firm's stock returns. Journal of Finance, 52, 943-963.

White, H. (1980). A heteroscedasticity-consistent covariance matrix estimator and a direct test for heteroscedasticity, Econometrica, 48, 817-838.

Wong, K.P. (2009). The effects of abandonment options on operating leverage and investment timing. International Review of Economics and Finance, 18, 162-171. 
Table 1 Annual distribution of the sampled

The sample consists of completed M\&A of US targets announced by US and non-US listed firms between 01/01/1985 and 31/12/2006 and recorded by the Security Data Corporation (SDC) that satisfy our selection criteria. The definition of each variable can be found in Appendix 1.

\begin{tabular}{|c|c|c|c|c|c|c|c|c|c|c|c|c|c|c|c|}
\hline Year & $\begin{array}{c}\text { FULL } \\
\text { SAMPLE }\end{array}$ & DOM & CBA & FOC & DIV & CASH & STOCK & MIXED & NPO & YPO & $d 1$ & DV & $\begin{array}{c}\text { PREM } \\
(\%)\end{array}$ & TCAR & ACAR \\
\hline 1985 & 1 & 1 & 0 & 1 & 0 & 1 & 0 & 0 & 1 & 0 & 1 & 6,605 & 97.47 & 18.44 & 4.98 \\
\hline 1986 & 38 & 32 & 6 & 19 & 19 & 32 & 3 & 3 & 29 & 9 & 25 & 448 & 44.41 & 28.17 & 0.60 \\
\hline 1987 & 42 & 30 & 12 & 18 & 24 & 31 & 2 & 9 & 15 & 27 & 25 & 245 & 41.65 & 21.78 & -0.43 \\
\hline 1988 & 77 & 53 & 24 & 30 & 47 & 54 & 8 & 15 & 50 & 27 & 30 & 360 & 62.68 & 30.15 & -0.13 \\
\hline 1989 & 60 & 40 & 20 & 29 & 31 & 40 & 13 & 7 & 40 & 20 & 27 & 637 & 48.04 & 23.40 & -0.43 \\
\hline 1990 & 38 & 33 & 5 & 17 & 21 & 20 & 12 & 6 & 30 & 8 & 17 & 355 & 61.80 & 29.44 & 0.53 \\
\hline 1991 & 27 & 26 & 1 & 12 & 15 & 8 & 11 & 8 & 21 & 6 & 8 & 142 & 62.44 & 28.97 & -2.22 \\
\hline 1992 & 29 & 29 & 0 & 18 & 11 & 10 & 8 & 11 & 16 & 13 & 8 & 177 & 58.57 & 29.73 & 1.72 \\
\hline 1993 & 39 & 37 & 2 & 22 & 17 & 10 & 15 & 14 & 31 & 8 & 12 & 561 & 60.08 & 19.03 & -0.81 \\
\hline 1994 & 51 & 40 & 11 & 27 & 24 & 19 & 21 & 11 & 41 & 10 & 12 & 929 & 58.50 & 26.26 & -0.92 \\
\hline 1995 & 95 & 87 & 8 & 57 & 38 & 33 & 38 & 24 & 77 & 18 & 32 & 545 & 57.09 & 25.48 & -1.37 \\
\hline 1996 & 114 & 100 & 14 & 64 & 50 & 25 & 54 & 35 & 93 & 21 & 36 & 784 & 56.10 & 26.47 & -0.50 \\
\hline 1997 & 155 & 139 & 16 & 88 & 67 & 39 & 62 & 54 & 140 & 15 & 51 & 596 & 65.51 & 24.73 & -0.66 \\
\hline 1998 & 167 & 143 & 24 & 103 & 64 & 53 & 62 & 52 & 149 & 18 & 51 & 1,378 & 60.30 & 28.22 & -1.76 \\
\hline 1999 & 181 & 147 & 34 & 102 & 79 & 73 & 60 & 48 & 157 & 24 & 58 & 1,636 & 70.76 & 33.60 & 0.16 \\
\hline 2000 & 160 & 123 & 37 & 88 & 72 & 54 & 58 & 48 & 142 & 18 & 53 & 1,409 & 60.13 & 37.03 & -2.61 \\
\hline 2001 & 120 & 102 & 18 & 74 & 46 & 37 & 51 & 32 & 108 & 12 & 26 & 1,103 & 62.53 & 37.72 & -0.92 \\
\hline 2002 & 60 & 54 & 6 & 36 & 24 & 30 & 20 & 10 & 50 & 10 & 11 & 1,504 & 63.85 & 41.25 & -1.92 \\
\hline 2003 & 97 & 83 & 14 & 68 & 29 & 43 & 22 & 32 & 86 & 11 & 18 & 828 & 63.28 & 33.22 & -2.57 \\
\hline 2004 & 85 & 74 & 11 & 56 & 29 & 39 & 20 & 26 & 81 & 4 & 14 & 981 & 53.81 & 26.24 & -2.00 \\
\hline 2005 & 102 & 86 & 16 & 66 & 36 & 51 & 18 & 33 & 94 & 8 & 18 & 2,319 & 50.87 & 27.90 & -0.13 \\
\hline 2006 & 101 & 82 & 19 & 53 & 48 & 67 & 11 & 23 & 96 & 5 & 23 & 2,741 & 44.16 & 26.16 & 0.52 \\
\hline Total & 1,839 & 1,541 & 298 & 1,048 & 791 & 769 & 569 & 501 & 1,547 & 292 & 556 & 26,283 & - & - & - \\
\hline$\%$ of All & - & $84 \%$ & $16 \%$ & $57 \%$ & $43 \%$ & $42 \%$ & $31 \%$ & $27 \%$ & $84 \%$ & $16 \%$ & $30 \%$ & - & - & - & - \\
\hline Average & - & - & - & - & - & - & - & - & - & & - & 1,195 & 59.27 & 28.34 & -0.49 \\
\hline
\end{tabular}




\section{Table 2 Summary statistics}

The sample consists of completed M\&A of US targets announced by US and non-US listed firms between 01/01/1985 and 31/12/2006 and recorded by the Security Data Corporation (SDC) that satisfy our selection criteria. The definition of each variable can be found in Appendix 1.

\section{Panel A}

\begin{tabular}{|c|c|c|c|c|c|c|c|c|c|c|c|c|c|}
\hline & \multirow[b]{2}{*}{$N$} & \multicolumn{2}{|c|}{ PREM (\%) } & \multicolumn{2}{|c|}{ ACAR $(\%)$} & \multicolumn{2}{|c|}{ TCAR (\%) } & \multicolumn{2}{|c|}{ DV in \$million } & \multicolumn{2}{|c|}{ TMV in \$million } & \multicolumn{2}{|c|}{ AMV in \$million } \\
\hline & & Mean & Median & Mean & Median & Mean & Median & Mean & Median & Mean & Median & Mean & Median \\
\hline Full Sample & 1,839 & 58.98 & 56.40 & -0.91 & -0.66 & 29.64 & 26.34 & 1,129 & 182 & 825 & 152 & 13,481 & 1,869 \\
\hline $\begin{array}{r}\text { Domestic (DOM) } \\
\text { Cross Border }\end{array}$ & 1,541 & 58.04 & 56.10 & -1.21 & -0.84 & 28.86 & 25.93 & 1,170 & 178 & 855 & 146 & 13,961 & 1,715 \\
\hline$(\mathrm{CBA})$ & 298 & 63.84 & 57.43 & 0.62 & 0.42 & 33.68 & 27.56 & 918 & 210 & 670 & 180 & 10,999 & 2,668 \\
\hline Focused (FOC) & 1,048 & 59.56 & 57.50 & -1.28 & -0.94 & 28.50 & 24.92 & 1,359 & 221 & 983 & 180 & 11,682 & 1,790 \\
\hline Diversified (DIV) & 791 & 58.21 & 54.14 & -0.42 & -0.35 & 31.15 & 28.02 & 825 & 147 & 615 & 121 & 15,864 & 2,076 \\
\hline Cash $(\mathrm{CASH})$ & 769 & 53.95 & 52.11 & 0.89 & 0.40 & 36.06 & 31.84 & 479 & 131 & 439 & 115 & 16,767 & 2,209 \\
\hline Mixed (MIXED) & 501 & 68.21 & 65.78 & -0.79 & -0.72 & 24.06 & 21.39 & 1,768 & 277 & 1,174 & 218 & 11,941 & 2,264 \\
\hline Stock (STOCK) & 569 & 57.65 & 56.45 & -3.45 & -2.66 & 25.87 & 24.34 & 1,445 & 235 & 1,040 & 164 & 10,395 & 1,330 \\
\hline No PreOwn & 1,547 & 60.78 & 57.57 & -1.22 & -0.84 & 30.47 & 27.63 & 1,265 & 220 & 868 & 152 & 14,144 & 1,929 \\
\hline Yes PreOwn & 292 & 49.47 & 47.88 & 0.75 & 0.23 & 25.24 & 20.18 & 407 & 49 & 599 & 146 & 9,966 & 1,510 \\
\hline$d 1$ & 556 & 61.71 & 58.69 & -0.14 & -0.58 & 32.12 & 27.10 & 1,240 & 153 & 892 & 120 & 9,274 & 1,362 \\
\hline
\end{tabular}

\section{Panel B}

\begin{tabular}{|c|c|c|c|c|c|c|c|}
\hline & & \multicolumn{3}{|c|}{ Measure $=$ PreOwn } & \multicolumn{3}{|c|}{ Measure $=d 1$} \\
\hline & & No PreOwn & Yes PreOwn & $\begin{array}{c}\text { PreOwn/ } \\
\text { All(\%) }\end{array}$ & All & $d 1$ & $d 1 / \operatorname{All}(\%)$ \\
\hline Full Sample & 1,839 & 1,547 & 292 & $16 \%$ & 1,839 & 556 & $30 \%$ \\
\hline Domestic & 1,541 & 1,327 & 214 & $14 \%$ & 1541 & 443 & $29 \%$ \\
\hline CBA & 298 & 220 & 78 & $26 \%$ & 298 & 113 & $38 \%$ \\
\hline
\end{tabular}


Table 3 Correlation matrix of main variables.

\begin{tabular}{|c|c|c|c|c|c|c|c|c|c|c|c|c|c|c|c|c|c|c|c|}
\hline & & (1) & (2) & (3) & (4) & (5) & (6) & (7) & $(8)$ & (9) & (10) & (11) & (12) & (13) & (14) & (15) & (16) & (17) & (18) \\
\hline ACAR & (1) & 1.00 & & & & & & & & & & & & & & & & & \\
\hline TCAR & (2) & 0.11 & 1.00 & & & & & & & & & & & & & & & & \\
\hline PREM & (3) & -0.03 & 0.40 & 1.00 & & & & & & & & & & & & & & & \\
\hline Yes toehold & (4) & 0.08 & -0.07 & -0.10 & 1.00 & & & & & & & & & & & & & & \\
\hline$d 1$ & (5) & 0.05 & 0.06 & 0.04 & 0.02 & 1.00 & & & & & & & & & & & & & \\
\hline CBA & (6) & 0.07 & 0.06 & 0.05 & 0.12 & 0.07 & 1.00 & & & & & & & & & & & & \\
\hline DIV & (7) & 0.05 & 0.05 & -0.02 & 0.04 & 0.06 & 0.03 & 1.00 & & & & & & & & & & & \\
\hline CASH & (8) & 0.16 & 0.19 & -0.10 & 0.19 & 0.02 & 0.19 & 0.13 & 1.00 & & & & & & & & & & \\
\hline TMV & (9) & -0.07 & -0.10 & -0.05 & -0.03 & 0.02 & -0.02 & -0.06 & -0.10 & 1.00 & & & & & & & & & \\
\hline AMV & (10) & 0.00 & 0.08 & 0.02 & -0.04 & -0.08 & -0.03 & 0.06 & 0.08 & 0.24 & 1.00 & & & & & & & & \\
\hline DV & (11) & -0.08 & -0.07 & 0.00 & -0.07 & 0.02 & -0.02 & -0.06 & -0.13 & 0.96 & 0.22 & 1.00 & & & & & & & \\
\hline TMTBV & (12) & -0.04 & -0.01 & 0.00 & -0.03 & 0.00 & 0.00 & -0.05 & -0.03 & 0.06 & 0.10 & 0.06 & 1.00 & & & & & & \\
\hline AMTBV & (13) & 0.00 & -0.01 & -0.01 & 0.03 & -0.03 & 0.00 & 0.00 & 0.03 & 0.02 & 0.04 & 0.02 & 0.01 & 1.00 & & & & & \\
\hline TCASH_RATIO & (14) & -0.11 & 0.08 & -0.04 & -0.09 & -0.08 & -0.03 & -0.05 & 0.02 & -0.01 & 0.24 & -0.02 & 0.08 & 0.04 & 1.00 & & & & \\
\hline TLEV_RATIO & (15) & 0.01 & -0.02 & 0.04 & -0.01 & -0.02 & -0.01 & -0.03 & -0.02 & 0.00 & 0.03 & 0.01 & 0.03 & 0.00 & -0.02 & 1.00 & & & \\
\hline ACASH_RATIO & (16) & -0.13 & 0.07 & -0.03 & -0.09 & 0.02 & -0.02 & -0.11 & -0.07 & -0.02 & 0.04 & -0.03 & 0.06 & 0.02 & 0.39 & -0.03 & 1.00 & & \\
\hline ALEV_RATIO & (17) & & 0.00 & -0.02 & & -0.03 & 0.02 & 0.03 & 0.02 & -0.02 & 0.01 & -0.01 & -0.03 & 0.09 & -0.06 & 0.00 & -0.05 & 1.00 & \\
\hline MBID & (18) & 0.01 & $\begin{array}{l}-0.02 \\
-0.00\end{array}$ & 0.02 & 0.00 & 0.07 & $\begin{array}{l}-0.01 \\
-0.01\end{array}$ & $\begin{array}{l}-0.01 \\
-0.01\end{array}$ & 0.04 & 0.05 & $\begin{array}{l}-0.03 \\
-0.03\end{array}$ & 0.06 & -0.01 & $\begin{array}{l}-0.01 \\
-0.01\end{array}$ & -0.07 & -0.01 & -0.06 & $\begin{array}{l}-0.06 \\
-\end{array}$ & 1.00 \\
\hline
\end{tabular}

Notes: This table reports the Pearson correlation coefficients between all the variables used in our analysis. Variable definitions can be found in Appendix 1. 
Table 4 Univariate Analysis of Premia

Acquisition premia based on Equation (1) for all deals, as well as deals grouped by the target firm's domicile, and pre-bid ownership of shares of the target by the acquirer, and also difference in premia from: (a) absence versus existence of pre-bid ownership, and (b) domestic and CBA deals, are presented. ALL refers to the total of sample deals; Domestic refers to domestic deals; CBA refers to foreign deals; No PreOwn refers to no pre-bid ownership prior to the M\&A; Yes PreOwn refers to existing ownership prior to the M\&A. ${ }^{a}, b$, and ${ }^{c}$ indicate significance at $1,5,10$ percent respectively.

\begin{tabular}{|c|c|c|c|c|}
\hline & All & No PreOwn & Yes PreOwn & $\begin{array}{c}\text { No PreOwn } \\
\text { vs. } \\
\text { Yes PreOwn }\end{array}$ \\
\hline \multicolumn{5}{|c|}{ Panel A: All (Prem defined in Eq. 1) } \\
\hline Mean & $58.98^{a}$ & $60.78^{a}$ & $49.47 \mathrm{a}$ & $11.31^{\mathrm{a}}$ \\
\hline Median & $56.40^{\mathrm{a}}$ & $57.57^{a}$ & $47.88^{\mathrm{a}}$ & $9.69^{\mathrm{a}}$ \\
\hline$N$ & 1,839 & 1,547 & 292 & \\
\hline \multicolumn{5}{|c|}{ Panel B1: Domestic (Prem defined in Eq. 1) } \\
\hline Mean & $58.04^{\mathrm{a}}$ & $60.10^{\mathrm{a}}$ & $45.31^{\mathrm{a}}$ & $14.79^{a}$ \\
\hline Median & $56.10^{\mathrm{a}}$ & $57.46^{\mathrm{a}}$ & $43.54^{\mathrm{a}}$ & $13.92^{\mathrm{a}}$ \\
\hline$N$ & 1,541 & 1,327 & 214 & \\
\hline \multicolumn{5}{|c|}{ Panel B2: Domestic (Target CAR $(t-20, t+2)$ defined in Eq. 3) } \\
\hline Mean & $28.86^{\mathrm{a}}$ & $29.82^{\mathrm{a}}$ & $22.92^{\mathrm{a}}$ & $6.90^{\mathrm{a}}$ \\
\hline Median & $25.93^{\mathrm{a}}$ & $27.09 \mathrm{a}$ & $18.72^{\mathrm{a}}$ & $8.37 \mathrm{a}$ \\
\hline $\mathrm{N}$ & 1,541 & 1,327 & 214 & \\
\hline \multicolumn{5}{|c|}{ Panel B3: Domestic (Acquirer CAR( $(t-2, t+2)$ defined in Eq. 3) } \\
\hline Mean & -1.21 & $-1.47 \mathrm{a}$ & 0.43 & $-1.90^{a}$ \\
\hline Median & -0.84 & $-0.94^{\mathrm{a}}$ & -0.12 & $-0.82^{a}$ \\
\hline $\mathrm{N}$ & 1,541 & 1,327 & 214 & \\
\hline \multicolumn{5}{|c|}{ Panel C1: CBA (Premia defined in Eq. 1) } \\
\hline Mean & $63.84^{\mathrm{a}}$ & $64.89^{a}$ & $60.87 a$ & 4.02 \\
\hline Median & $57.43^{\mathrm{a}}$ & $60.69^{a}$ & $52.51^{\mathrm{a}}$ & 8.18 \\
\hline$N$ & 298 & 220 & 78 & \\
\hline \multicolumn{5}{|c|}{ Panel C2: CBA (Target CAR(t-20,t+2) defined in Eq. 3 ) } \\
\hline Mean & $33.68^{\mathrm{a}}$ & $34.41^{\mathrm{a}}$ & $31.59^{a}$ & 2.82 \\
\hline Median & $27.56^{\mathrm{a}}$ & $29.09^{a}$ & $23.88^{\mathrm{a}}$ & $5.21^{\mathrm{c}}$ \\
\hline$N$ & 298 & 220 & 78 & \\
\hline \multicolumn{5}{|c|}{ Panel C3: CBA (Acquirer CAR $(t-2, t+2)$ defined in Eq. 3) } \\
\hline Mean & 0.62 & $0.26^{\mathrm{a}}$ & $1.65^{\mathrm{b}}$ & $-1.39^{c}$ \\
\hline Median & 0.42 & -0.02 & 0.64 & $-0.66^{c}$ \\
\hline$N$ & 298 & 220 & 78 & \\
\hline
\end{tabular}


Table 5 Multiple regression analysis on the Takeover Premia, Target CAR, and Acquirer CAR

Panel A reports the results from the multivariate analysis on acquisition premia (as defined in equation 1) and announcement period market-adjusted abnormal returns of targets and acquirers (as defined in equation 3) are regressed on a set of explanatory variables. Panel B reports the corresponding $\lambda_{C B A}$ for each model in Panel A after correcting for self-selection in the choice of firms to conduct CBAs or not. Equation (4) is estimated using the ordinary least squares (OLS) method. The intercept $\left(\alpha_{i, t}^{1}\right)$ measures premia and targets' or acquirers' abnormal returns after accounting for the effects of explanatory variables. The dependent variable is regressed against a set of explanatory variables which include toehold investment, $d 1$ dummy, $C B A$ dummy, diversifying M\&A dummy, log of acquirer size, log of deal value, target and acquirer MTBV, target and acquire acquirer cash ratio, target and acquirer debt/equity (leverage) ratio, multiple bid dummy, cash financing dummy, and year fixed effects. Variable definitions can be found in Appendix 1. In Panel $B, \lambda_{C B A}$ refers to the inverse Mills ratio (IMR) from the Heckman two-stage model. a, b, and ${ }^{c}$ indicate significance at 1,5 and $10 \%$ respectively.

\begin{tabular}{|c|c|c|c|c|c|c|c|c|c|c|c|c|}
\hline & \multicolumn{4}{|c|}{ Takeover Premia (Equation 1) } & \multicolumn{4}{|c|}{ Target $C A R(t-20, t+2)$ (Equation 3$)$} & \multicolumn{4}{|c|}{ Acquirer $C A R(t-2, t+2)$ (Equation 3) } \\
\hline \multicolumn{13}{|c|}{ Panel A - Regression models } \\
\hline Model & $(1)$ & $(2)$ & (3) & $(4)$ & (5) & $(6)$ & (7) & $(8)$ & $(9)$ & $(10)$ & (11) & $(12)$ \\
\hline Yes PreOwn & $-9.385^{a}$ & $-11.032^{\mathrm{a}}$ & $-9.342^{\mathrm{a}}$ & $-10.031^{a}$ & $-5.945^{a}$ & $-6.727^{a}$ & $-5.908^{a}$ & $-5.407^{a}$ & $1.198^{\mathrm{b}}$ & $1.165^{c}$ & $1.198^{b}$ & $1.424^{\mathrm{a}}$ \\
\hline$d 1$ & $4.295^{\mathrm{b}}$ & $4.234^{\mathrm{b}}$ & $5.581^{\mathrm{b}}$ & $3.958^{\mathrm{c}}$ & $4.195^{a}$ & $4.165^{\mathrm{a}}$ & $5.300^{\mathrm{a}}$ & $4.476^{\mathrm{a}}$ & $1.039^{\mathrm{b}}$ & $1.038^{\mathrm{b}}$ & $1.050^{c}$ & $1.158^{\mathrm{b}}$ \\
\hline$C B A$ & $8.863^{\mathrm{a}}$ & $7.274^{\mathrm{a}}$ & $11.443^{\mathrm{a}}$ & $8.257^{\mathrm{a}}$ & $2.937^{\mathrm{c}}$ & 2.183 & $5.157^{\mathrm{b}}$ & $3.441^{\mathrm{c}}$ & $0.993^{b}$ & $0.961^{\mathrm{c}}$ & $1.015^{\mathrm{c}}$ & $1.205^{\mathrm{a}}$ \\
\hline DIV & -2.241 & -2.145 & -2.364 & -2.175 & 0.007 & 0.053 & -0.099 & -0.049 & -0.009 & -0.007 & -0.010 & -0.032 \\
\hline Yes PreOwn $\times C B A$ & & 6.747 & & & & 3.201 & & & & 0.136 & & \\
\hline$d 1 \times C B A$ & \multicolumn{4}{|c|}{-7.162} & \multicolumn{4}{|c|}{$-6.160^{c}$} & \multicolumn{4}{|c|}{-0.060} \\
\hline$d 1 \times$ Yes PreOwn $\times C B A$ & & & & 6.404 & & & & -5.337 & & & & $-2.241^{c}$ \\
\hline $\operatorname{Ln}\left(A M V_{-20}\right)$ & $3.844^{\mathrm{a}}$ & $3.803^{\mathrm{a}}$ & $3.866^{\mathrm{a}}$ & $3.805^{\mathrm{a}}$ & $3.028^{\mathrm{a}}$ & $3.008^{\mathrm{a}}$ & $3.046^{\mathrm{a}}$ & $3.060^{\mathrm{a}}$ & 0.166 & 0.165 & 0.166 & 0.179 \\
\hline $\operatorname{Ln}\left(T M V_{t-43}\right)$ & $-4.457^{a}$ & $-4.424^{a}$ & $-4.502^{\mathrm{a}}$ & $-4.428^{a}$ & $-5.076^{a}$ & $-5.061^{a}$ & $-5.115^{a}$ & $-5.100^{\mathrm{a}}$ & $-0.825^{a}$ & $-0.824^{a}$ & $-0.825^{a}$ & $-0.835^{a}$ \\
\hline$A M T B V_{t-20}$ & -1.564 & -1.526 & -1.772 & -1.491 & -2.456 & -2.438 & -2.635 & -2.517 & -0.038 & -0.037 & -0.040 & -0.063 \\
\hline$T M T B V_{t-43}$ & -1.086 & -1.061 & -1.074 & -1.093 & -2.210 & -2.198 & -2.199 & -2.204 & -0.398 & -0.398 & -0.398 & -0.396 \\
\hline ACASH_RATIO & -6.886 & -7.070 & -6.780 & -7.008 & $6.941^{c}$ & $6.854^{c}$ & $7.033^{c}$ & $7.043^{c}$ & $-4.922^{\mathrm{a}}$ & $-4.925^{a}$ & $-4.921^{\mathrm{a}}$ & $-4.879^{\mathrm{a}}$ \\
\hline TCASH_RATIO & $-11.442^{b}$ & $-11.456^{b}$ & $-11.646^{b}$ & $-11.449^{b}$ & -0.837 & -0.843 & -1.012 & -0.831 & $-3.828^{\mathrm{a}}$ & $-3.828^{a}$ & $-3.829^{a}$ & $-3.825^{a}$ \\
\hline$A L E V \_R A T I O$ & $-0.232^{b}$ & $-0.236^{b}$ & $-0.231^{b}$ & $-0.234^{b}$ & -0.091 & -0.093 & -0.090 & -0.090 & -0.025 & -0.025 & -0.025 & -0.024 \\
\hline TLEV_RATIO & $0.061^{\mathrm{a}}$ & $0.061^{\mathrm{a}}$ & $0.061^{a}$ & $0.061^{\mathrm{a}}$ & $-0.013^{b}$ & $-0.013^{b}$ & $-0.013^{b}$ & $-0.013^{b}$ & $0.007^{\mathrm{a}}$ & $0.007^{a}$ & $0.007^{a}$ & $0.007^{a}$ \\
\hline$M B I D$ & 4.695 & 4.836 & 4.744 & 4.724 & -0.763 & -0.696 & -0.722 & -0.787 & 0.134 & 0.137 & 0.134 & 0.124 \\
\hline CASH & $-11.787^{a}$ & $-11.638^{a}$ & $-11.689^{a}$ & $-11.746^{a}$ & $8.351^{\mathrm{a}}$ & $8.422^{\mathrm{a}}$ & $8.436^{a}$ & $8.317^{a}$ & $2.280^{\mathrm{a}}$ & $2.283^{\mathrm{a}}$ & $2.281^{\mathrm{a}}$ & $2.265^{a}$ \\
\hline Intercept & $60.986^{\mathrm{a}}$ & $61.196^{\mathrm{a}}$ & $60.828^{\mathrm{a}}$ & $61.176^{\mathrm{a}}$ & $25.000^{a}$ & $25.100^{\mathrm{a}}$ & $24.864^{\mathrm{a}}$ & $24.841^{\mathrm{a}}$ & 0.334 & 0.338 & 0.333 & 0.267 \\
\hline YFE & Yes & Yes & Yes & Yes & Yes & Yes & Yes & Yes & Yes & Yes & Yes & Yes \\
\hline F-Stat & $6.75^{\mathrm{a}}$ & $6.45 a$ & $6.48^{\mathrm{a}}$ & $6.41^{\mathrm{a}}$ & $15.08^{\mathrm{a}}$ & $14.28^{\mathrm{a}}$ & $14.43^{\mathrm{a}}$ & $14.30^{\mathrm{a}}$ & $7.83^{\mathrm{a}}$ & $7.31^{\mathrm{a}}$ & $7.59^{\mathrm{a}}$ & $7.48^{\mathrm{a}}$ \\
\hline R-squared (in \%) & 5.93 & 5.99 & 6.02 & 5.96 & 12.34 & 12.37 & 12.49 & 12.39 & 6.81 & 6.88 & 6.49 & 6.29 \\
\hline $\mathrm{N}$ & 1,839 & 1,839 & 1,839 & 1,839 & 1,839 & 1,839 & 1,839 & 1,839 & 1,839 & 1,839 & 1,839 & 1,839 \\
\hline \multicolumn{13}{|c|}{ Panel B - Inverse Mills Ratio (IMR) from the Heckman two-stage model } \\
\hline$C B A$ & $8.394^{\mathrm{a}}$ & $6.791^{\mathrm{b}}$ & $10.774^{\mathrm{a}}$ & $7.669^{\mathrm{a}}$ & 2.707 & 1.947 & $4.830^{\mathrm{c}}$ & $3.156^{\mathrm{c}}$ & $1.022^{\mathrm{b}}$ & $0.991^{c}$ & $1.056^{c}$ & $1.242^{\mathrm{a}}$ \\
\hline$\lambda_{C B A}$ & $-117.829^{\mathrm{a}}$ & $-117.864^{\mathrm{a}}$ & $-117.398^{\mathrm{a}}$ & $-118.322^{\mathrm{a}}$ & $-57.729^{\mathrm{a}}$ & $-57.745^{\mathrm{a}}$ & $-57.344^{\mathrm{a}}$ & $-57.424^{\mathrm{a}}$ & $7.228^{\mathrm{c}}$ & $7.227^{c}$ & $7.234^{\mathrm{c}}$ & $7.377^{\mathrm{c}}$ \\
\hline
\end{tabular}


Figure 1 Annual distribution of deals according to the pre-bid ownership level (from Table 1) NPO: No pre-bid ownership prior to completed M\&A. YPO: Pre-bid ownership present prior to M\&A.

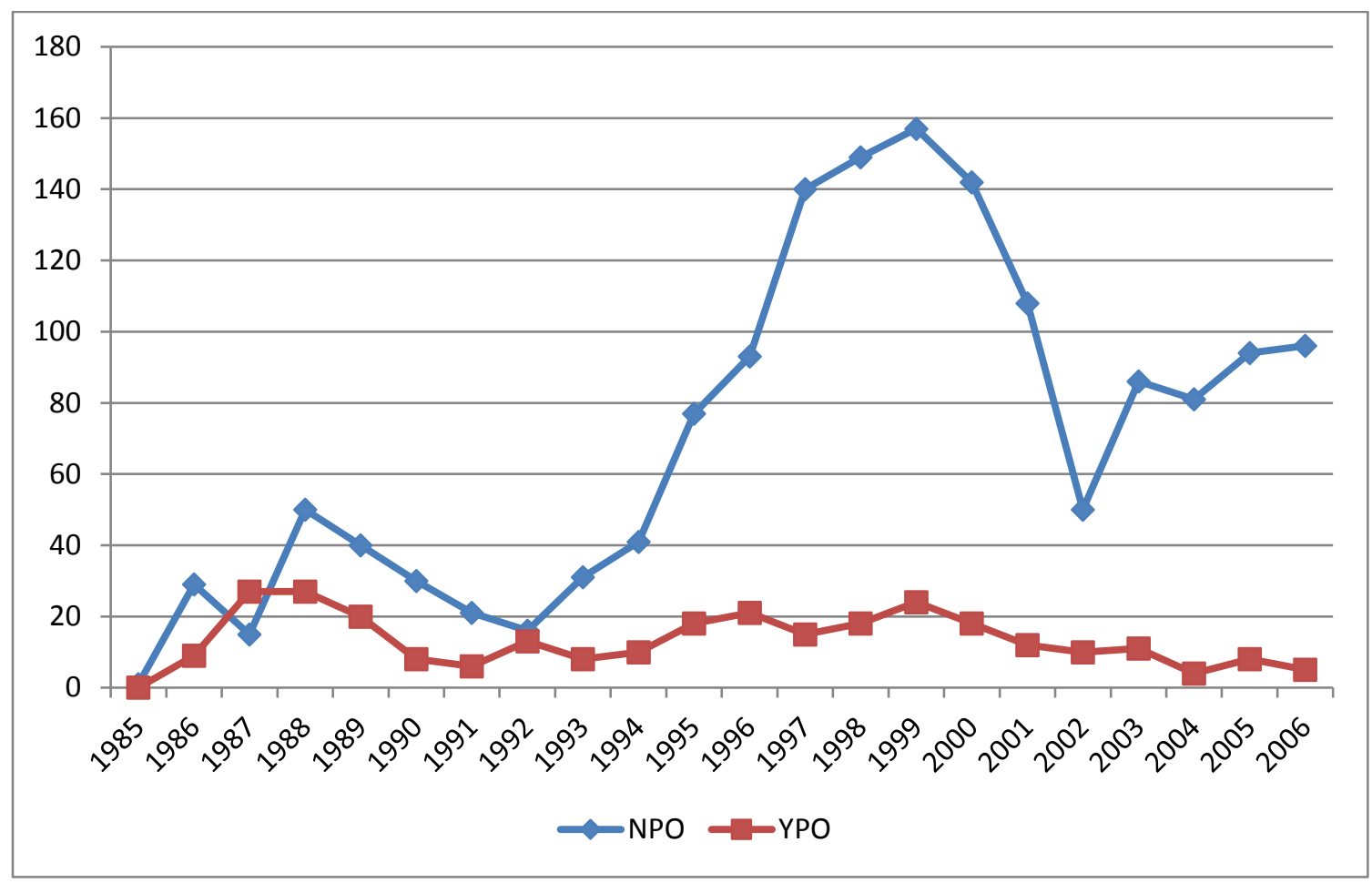

